\title{
Pembuatan Kebun Rempah "Seruputan" sebagai Upaya Pengembangan Kampung Mompreneur bagi Warga Binaan PKK Putat Wetan
}

\author{
Nurul Dzakiya ${ }^{11^{*}}$, Elisabeth Amanda E.F. Sari Lewoema², Rahma Laila Fitriah³, Zhulfikar Esa Amirul Mu'minin ${ }^{4}$, \\ Ryand Martin Sinaga ${ }^{5}$ \\ 1 Jurusan Teknik Geologi, Institut Sains \& Teknologi AKPRIND Yogyakarta \\ 2,3,4,5 Himpunan Mahasiswa Teknik Geologi "GAIA", Institut Sains \& Teknologi AKPRIND Yogyakarta
}

\section{ARTICLE INFO}

Riwayat Artikel:

Draft diterima: 08 Oktober 2021

Revisi diterima: 02 Desember 2021

Diterima: 22 Desember 2021

Tersedia Online: 27 Desember 2021

Corresponding author:

dzakiya@akprind.ac.id

Citation: Dzakiya. N, Lewoema. E.A. E.F, Fitriah. R. L, Mu'mini. Z. E. A, Sinaga. R. M. 2021. Pembuatan Kebun Rempah

"Seruputan" sebagai Upaya

Pengembangan Kampung Mompreneur bagi Warga Binaa PKK Putat Wetan.

ICOMES: Indonesian Journal of

Community Empowerment and Service.

1(1), pp: 21-25

\begin{abstract}
ABSTRAK
Kampung Mompreneur yang saat ini sudah berdiri di bawah binaan Tim Program Pengembangan dan Pemberdayaan Desa (P3D) HMTG “GAIA" telah berhasil dengan produk minuman tradisional "seruputan" yang sudah mampu terjual hingga di luar Yogyakarta. Namun kendala saat ini, produksi produk terkendala karena kurangnya bahan baku rempah utama. Disisi lain, terdapat lahan warga yang belum dimanfaatkan. Tujuan dari pengabdian ini adalah menambah lahan rempah dengan memanfaatkan lahan warga yang belum produktif. Hasilnya telah dilakukan pembuatan kebun rempah "seruputan" bersama dengan warga binaan dicapai sesuai target dengan menanam aneka rempah yang memicu ide usaha dalam inovasi produk 'seruputan' aneka rasa dan produk seruputan dalam bentuk lainnya.
\end{abstract}

Kata kunci: kebun rempah, minuman tradisional, pemberdayaan desa, putat wetan

\begin{abstract}
Mompreneur village, which is currently established under the guidance of the HMTG "GAIA" Village Development and Empowerment Program Team (P3D), has succeeded with the traditional drink product "seruputan" which has been able to be sold outside of Yogyakarta. However, the current problem is that the production of the product is constrained due to the lack of raw materials for the main spices. On the other hand, there are residents' land that has not been used. The purpose of this service is to increase the spice land by utilizing the land of residents who are not yet productive. As a result, the creation of a "sruputan" spice garden together with the assisted residents was achieved according to the target by planting various spices that sparked business ideas in innovating various flavors of 'sruputan' products and other forms of slurry products.
\end{abstract}

\section{PENDAHULUAN}

Kampung Mompreneur merupakan mitra binaan program pengembangan dan pemberdayaan desa (P3D) Himpunan Mahasiswa Teknik Geologi IST AKPRIND yang merupakan warga PKK Putat Wetan yang awalnya tidak produktif menjadi produktif dengan produk unggulan minuman tradisional "Seruputan". Produk seruputan sebelum dilakukan pembinaan hanya laku 50 botol per bulan selama pendampingan sejak awal tahun 2020 mampu meningkatkan penjualan produk hingga 1000 botol per bulan (Dzakiya, 2020). Mitra telah dibekali ilmu kewirausahaan agar mandiri dan produktif dengan pengembangan ilmu kewirausahaan sebagai sarana yang memicu teknologi baru untuk menghasilkan inovasi dan daya kreatifitas (Utami dkk, 2020); (Miguel, 2013 dalam
Hermuningsih, 2018). Dampaknya sangat penting dalam pertumbuhan ekonomi mitra binaan sehingga mitra/masyarakat berperan signifikan dalam mewujudkan kualitas dirinya (Frinces, 2010) dan lebih berpengaruh positif terhadap peningkatan ekonomi (Hafer, 2013) .

Inovasi yang telah dilakukan sebelumnya fokus pada pengembangan produk minuman "seruputan" dari perbaikan kemasan, logo dan pemasaran. Namun setelah produk ini dipasarkan secara luas, kendala adanya pemberlakuan PPKM. Setelah level PPKM menurun di Provinsi DI Yogyakarta geliat kegiatan ekonomi warga binaan juga mulai bangkit sehingga proses produksi minuman seruputan kini dilakukan mengalami kendala karena kebutuhan bahan baku rempah-rempah mengalami 
lonjakan harga dan hasil kebun warga yang ditanam mandiri di masing-masing pemukiman belum mampu mencukupi kebutuhan. Padahal di lokasi binaan terdapat banyak lahan kosong yang belum dimanfaatkan secara optimal. Hal ini dicarikan solusi dengan membuat kebun rempah "Seruputan".

Harapan besar dari kegiatan ini adalah agar warga desa/mitra dapat memenuhi kebutuhannya sendiri dan tidak tergantung pada bantuan dari pemerintah (Wardoyo, 2015). Harapan itu akan dapat terwujud apabila kegiatan pemberdayaan masyarakat di wilayah sekitar berjalan kontinyu. Selain itu perumusan tindakan pemberdayaan masyarakat perlu memperhatikan komitmen dari individu atau anggota (Nugrahani, 2018).

\section{METODE PELAKSANAAN}

Pengabdian masyarakat di Padukuhan Putat Wetan ini diberi nama kegiatan pembuatan kebun rempah "Seruputan". Melibatkan 15 orang yang tercatat aktif dengan rentang usia produktif, yakni 30-50 tahun (Dzakiya, 2021).

Tujuannya agar kebun tersebut mampu memenuhi kebutuhan produksi "Seruputan" yang semakin besar.

a) Metode pelaksanaan yang digunakan

Pelaksanaan pengabdian menggunakan metode partisipatif dari warga dan metode pendampingan dalam tiap kegiatan serta kegiatan praktek mandiri.

\section{- Metode partisipatif}

Pelaksanaan pembuatan kebun rempah dilakukan dengan metode partisipatif yaitu dengan melibatkan peran aktif pihak-pihak yang terkait agar warga terlibat langsung dalam kegiatan pembuatan kebun rempah. Hal ini bertujuan agar rasa memilikinya tinggi sehingga mampu bersama-sama menjaga dan merawat hasil kegiatan bersama.

\section{- Metode pendampingan}

Metode ini dilakukan saat kegiatan juga didampingi oleh dosen dan mahasiswa dengan beberapa pendekatan yaitu komunikasi yang santai dan santun, memberikan informasi tentang tatacara penggunaan media tanam beserta pupuk yang bijak agar kebun tumbuh dengan baik. Selain itu dilakukan edukasi tentang manfaat menanam beberapa jenis rempah yang belum ada sebelumnya seperti: Bunga Telang, Jahe Merah, Temulawak, dan rempah lainnya. Setelah menanam, setiap tanaman berbeda diberi papan nama agar dapat menjadi edukasi buat warga di desa dalam mengenal macam-macam rempah atau tanaman obat keluarga (TOGA) bersama dengan manfaat dan nilai ekonominya jika dikembangkan menjadi suatu produk (Praditya, 2021). Metode ini juga dapat digunakan untuk menganalisis faktor-faktor yang mempengaruhi motivasi mitra dalam berwirausaha (Pranoto, 2020).

b) Langkah-langkah pelaksanaan

- Focus Grup Discussion (FGD) dan sosialisasi

- Kerjabakti membuat pagar dan gapura kebun

- Membersihkan lahan

- Menggunakan media tanam dan pupuk sesuai dengan kebutuhan

- Menggali dan menanam aneka tanaman rempah

- Merawat dan menjaga kebun sesuai jadwal piket

c) Indikator keberhasilan kegiatan

Indikator keberhasilan kegiatan ini diukur secara fisik dan non fisik dari perubahan dan peningkatan yang terjadi sesuai target dan tujuan pengabdian.

d) Alat dan Bahan

Alat dan Bahan yang diperlukan adalah segala hal yang dubutuhkan dalam kegiatan berkebun seperti bibit aneka rempah-rempah, media tanam, pupuk, peralatan kebun dan lahan. Kegiatan dilaksanakan saat pagi hingga menjelang siang hari pada Sabtu, 18 September 2021 dan dilanjutkan di hari berikutnya selama tiga bulan kedepannya.

\section{HASIL DAN PEMBAHASAN}

Partisipasi mitra sangat tinggi dengan berperan aktif dan ikut terlibat secara langsung dalam pembuatan kebun rempah 'seruputan'. Selain itu, mereka berkontribusi menyediaan lahan, alat-alat serta logsitik selama kerjabakti berlangsung. Hasil pelaksanaan yang didapatkan, yaitu:

- Focus Grup Discussion (FGD) dan sosialisasi dengan mitra untuk mendiskusikan lahan dan jenis rempah yang akan digunakan disetujui oleh satu warga sekitar dengan merelakan lahan tidurnya untuk dimanfaatkan sebagai kebun rempah yang letaknya berada di selatan desa dan dekat dengan rumah produksi seruputan.

- Kerjabakti antara warga dan mahasiswa beserta dosen pendamping membuat pagar dan gapura kebun dengan bambu terlaksana sesuai dengan jadwal yang disepakati dan dilakukan oleh mahasiswa bersama kaum laki-laki desa. Proses pembersihan lahan yang akan dijadikan kebun rempah seperti pada Gambar 1. Lahan yang digunakan merupakan lahan kosong warga yang dengan suka rela digunakan sebagai kebun untuk mendukung program pengembangan Kampung Mompreneur. Peran serta warga sangat besar seperti mereka dengan suka rela Tujuan dibuat pagar dari bambu dan dipasang mengelilingi kebun agar terhindar dari gangguan sekitar seperti ayam dan lainnya. 


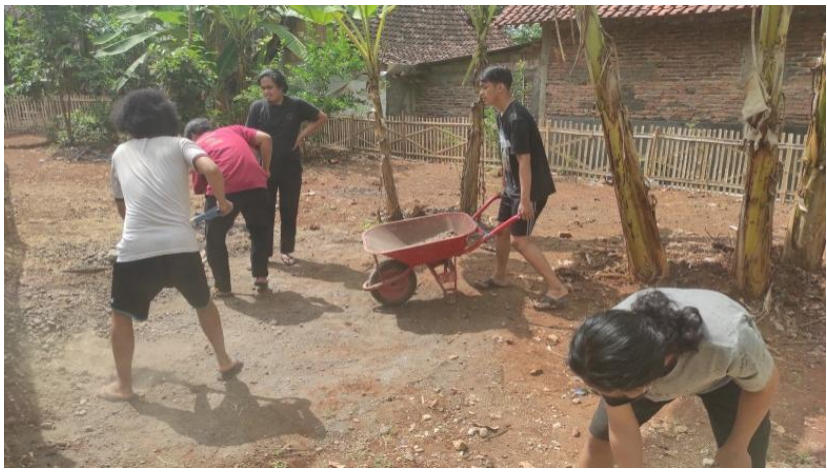

Gambar 1. Proses pembersihan lahan yang akan dijadikan kebun rempah "Seruputan" dan pembuatan pagar dari bambu

- Menggali dan menanam aneka tanaman rempah untuk kebutuhan bahan baku minuman seruputan. Kegiatan berikutnya adalah membuat lubang-lubang yang akan dilakukan penanaman bibit rempah utama seperti pada Gambar 2. Bibit rempah utama seperti: Jeruk nipis, sereh, jahe dan lainnya. Bibit yang ditanam merupakan hibah dari program P3D dan dilakukan secara swadaya oleh mitra dan mahasiswa. Selama proses ini tidak ada kendala yang serius sehingga kegiatan berjalan sesuai rencana untuk mendukung Pengembangan Kampung Mompreneur dan mampu memenuhi kebutuhan bahan baku seruputan.

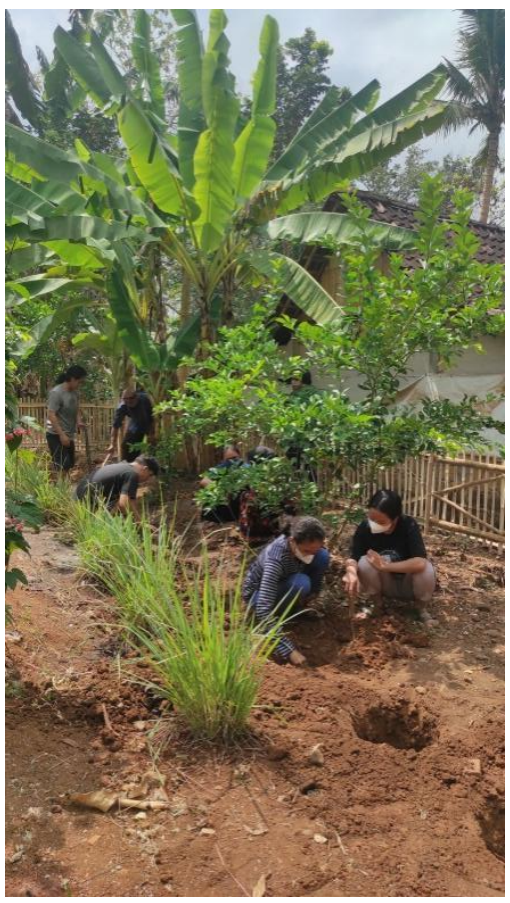

Gambar 2. Proses pelubangan pada tanah yang akan ditanam bibit-bibit rempah

- Merawat dan menjaga kebun sesuai jadwal piket dengan jobdesk divisi produksi yang telah dibagi dalam program Kampung Mompreneur sebelumnya. Setelah proses penanaman dilakukan proses perawatan dan penumbuhan bibit agar dapat tumbuh subur dan menghasilkan buah dan rempah yang melimpah. Proses perawatan diserahkan langsung kepada warga agar dilanjutkan pada tahap berikutnya seperti pada Gambar 3 .

- Kebun rempah "Seruputan" yang merupakan hasil dari kerjasama yang kompak antara warga dan mahasiwa beserta dukungan pihak kampus telah terwujud seperti pada Gambar 4. Kebun ini menjadi kebun rempah pertama yang dibuat dan akan dikembangkan dengan menambah beberapa lahan lagi agar meningkatkan perekonomian warga dalam penemuhan kebutuhan rempah-rempah masyarakat sekitar dan dapat dijual mengingat rempahrempah menjadi kebutuhan pokok masyarakat Kabupaten Gunung Kidul dan sekitarnya.

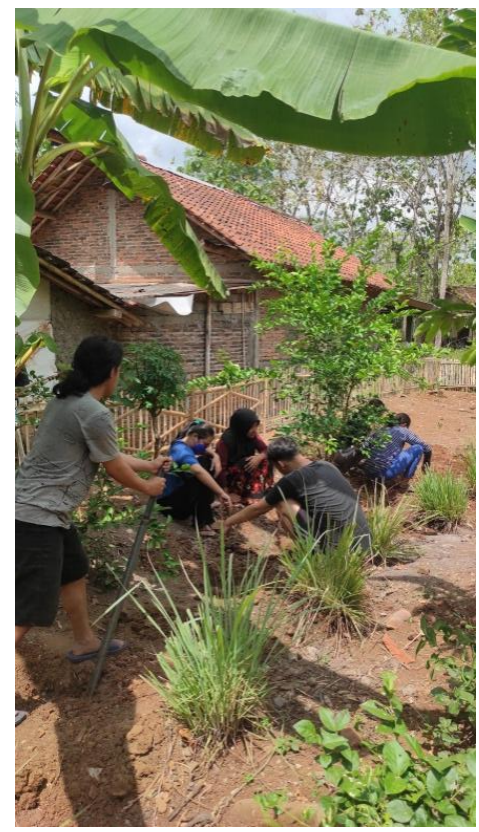

Gambar 3. Proses penanaman beberapa bibit rempah sebagai bahan baku "Seruputan

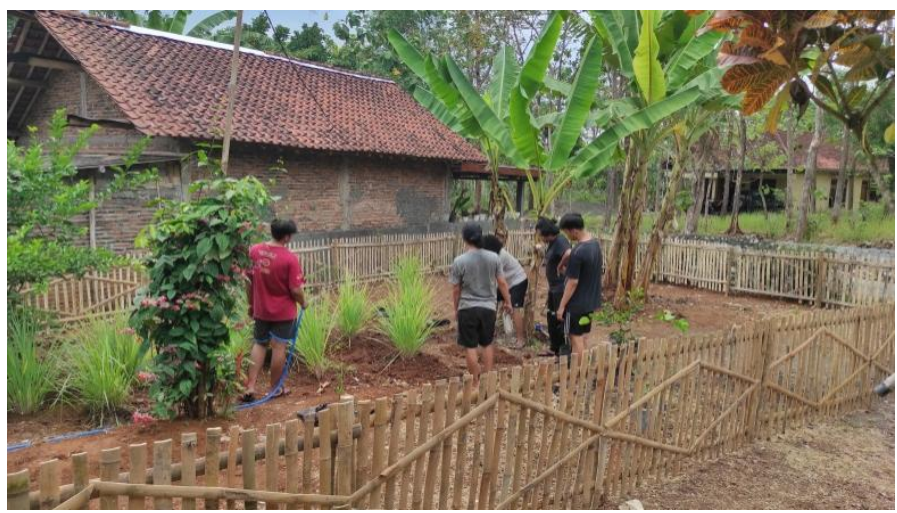

Gambar 4. Proses berkebun dan perawatan yang dilakukan untuk menyuburkan bibit tanaman 
Mitra telah dibekali ilmu kewirausahaan agar mandiri dan produktif. Adanya kebun rempah sebagai usaha pengembangan Kampung Mompreneur sudah mampu memicu ide baru warga untuk berinovasi mengasilkan produk minuman seruputan aneka rasa berikutnya, seperti: seruputan rasa temulawak, jahe merah, bunga telang dan lainnya. Selain itu, keinginan mitra dalam berwirausaha juga meningkat dengan antusiasnya mereka terlibat dalam pelatihan bisnis digital dan marketing, pengolahan kebun dan memberi ide pengembangan produk lainnyadari hasil kebun kedepannya. Produk lain yang ingin dikembangkan selain inovasi varian rasa juga memicu ide membuat produk lain seperti: Seruputan bentuk sirop, permen dan produk bubuk dalam kemasan saset agar nilai jual hasil kebun memiliki nilai jual yang lebih tinggi. Berdasarkan hal ini, insting dan naluri dalam berwirausaha sudah mengalami peningkatan. Indikator keberhasilan pelaksanaan program diukur dengan melakukan pengamatan dari segi perubahandan peningkatan yang terjadi secara fisik dan nonfisik.

a) Secara fisik

- Warga masyarakat sasaran binaan 15 orang terlibat semua dalam kegiatan tersebut. Warga lain yang tidak secara langsung terlibat dalam pembuatan kebun berpartisipasi dengan menyediakan logistik berupa makanan dan minuman. Meski pun target binaan adalah ibu-ibu namun bapak-bapak warga sekitar juga antusias membantu khususnya dalam kegiatan kerjabakti membuat pagar dan gapura kebun hingga Kebun Rempah "seruputan" berhasil dibuat dalam kurun waktu selama pelaksanaan program pengembangan dan pemberdayaan desa (P3D).

- Semula lahan pekarangan warga tidak produktif dan hanya dibiarkan tanpa ada perawatan sehingga terlihat kotor. Setelah menjadi kebun rempah 'seruputan' maka lahan tersebut dapat digunakan untuk budidaya tanaman obat dan keluarga (toga) yang hasilnya dapat digunakan bahan baku produk seruputan agar banyak variasi rasanya.

b) Secara non-fisik

Indikator keberhasilan secara nonfisik, mitra binaan semangat selama pelaksanaan program pembuatan kebun rempah serta mitra mendapatkan tambahan pengetahuan tentang manfaat adanya tanaman yang telah ditanam di kebun rempah ini sebagai sarana produksi dan edukasi untuk warga sekitar.

\section{KESIMPULAN}

Kebun rempah "Seruputan" telah selesai dibuat bersama mitra binaan bersama mitra PKK Putat Wetan dengan metode partisipatif dan pendampingan. Indikator keberhasilan kegiatan diukur dengan pengamatan secara fisik dan non-fisik dari perubahan dan peningkatan yang terjadi. Hasil pelaksanaan secara keseluruhan, tujuan pengabdian sebagai pengembangan kampung mompreneur telah terlaksana sesuai yang direncakan dengan bantuan dan dukungan penuh dari mitra binaan dan pemerintah desa setempat.

\section{UCAPAN TERIMAKASIH}

Terimakasih kepada Kemendikbud-ristek yang telah memberi hibah melalui Program P3D untuk pengembangan Kampung Mompreneur yang diinisiasi oleh Himpunan Mahasiswa Teknik Geologi "GAIA" IST AKPRIND Yogyakarta serta terimakasih yang sebesar-besarnya kepada Mitra Binaan PKK Putat Wetan dan pemerintah desa setempat dalam mendukung program ini.

\section{DAFTAR PUSTAKA}

Dzakiya, N., Costa, F.S. S.D., Prasetyo R.E, Bawono, D.C., Ardianto, A., (2020), Kampung Mompreneur: Pembinaan Dan Pemberdayaan Anggota Pkk Putat Wetan Berbasis Kewirausaan, Prosiding Seminar Nasional ke-6 LPPM UPN 'Veteran' Yogayakarta, Yogyakarta, 3 November.

Dzakiya, N., Fitria, R.L2, Mu'minin, Z.E.A, Tsanie, R.A., Amanda, E., Sinaga, R.M., Safriani, M.F., Pangaribuan, M.P., (2021), Optimalisasi Produk Minuman Tradisional Seruputan PKK Putat Wetan dengan Program Kampung Mompreneur. Jurnal Abdimas PHB Vol.4, No.2.

Frinces, Z.H., (2010), Pentingnya Profesi Wirausaha di Indonesia, Jurnal Ekonomi dan Pendidikan, Vol. 7, No. 1, April 2010.

Hafer, R.W., (2013), Entrepreneurship and State Economic Growth, Journal of Entrepreneurshop and Public Policy, Vol. 2, Issue 1, pp.67-79.

Hermuningsih, S., Widiastuti, R., Kurniawan, VRB., (2018), Program Pengembangankewirausahaan (PPK) Di Universitas Sarjanawiyata Tamansiswa, Jurnal Dharma Bakti, Vol 1. No1.

Nugrahani, T.S., Susetyo, H.B., Birsyada, M.I., (2018), Budidaya Toga Dan Pembuatan Pupuk Kompos Sebagai Upaya Peningkatan Penghasilan Warga Dusun Salakan, Jurnal Dharma Bakti, Vol 1, No 1.

Praditya, F.A., Dzakiya, N., Afifa, W.H., Latifah, R.N., Nurady, D., (2021), Pemanfaatan Lahan Bantaran Rel Sebagai "Kebun Desa Mandiri Di Padukuhan Banyumeneng, Jurnal Dharma Bakti Vol, 4. No 2.

Pranoto, A., Sulistyaningsih, E., Dzakiya, N., (2020). Analisis Faktor-Faktor Yang Mempengaruhi Motivasi Wirausaha Era Revolusi Industri 4.0 Mahasiswa IST Akprind 
Yogyakarta, Jurnal Pendidikan Vokasi Otomotif, Vol 3 No 1.

Utami, M.P., Kencanawati, K., Rizkiah, R., Yulianti, D., (2020). Pembuatan Sabun Padat di TKIT Qurrata A'yun di Cimahi, Jurnal Dharma Bakti, Vol. 3 No 1.

Wardoyo, H., (2015), Penguatan Pengelolaan keuangan Desa dan Optimalisasi Peran BUMDES Sebuah Upaya Menuju Desa Mandiri dan Kredibel di Kabupaten Kulon Progo, Seminar Nasional Temu Forum Dosen Akuntansi Sektor Publik, Universitas Atma Jaya Yogyakarta, 9 April 2015. 